\title{
Humic fractions as indicators of soil organic matter responses to clear-cutting in the mountain and lowland conditions of south-western Poland
}

\author{
Elzbieta Jamroz ${ }^{1}$ and Maria Jerzykiewicz ${ }^{2}$ \\ ${ }^{1}$ Wrocław University of Environmental and Life Sciences \\ ${ }^{2}$ Wroclaw University Faculty of Chemistry
}

March 31, 2021

\begin{abstract}
Clear-cutting means forest removing (stem only) and is the most common type of forest harvesting but undoubtedly has a negative impact on the $\mathrm{C}$ budget in soils. This work aimed to describe responses of soil organic matter in the forest soils to forest removing under temperate climate conditions of lowland and mountain regions in south-western Poland. Using advanced instrumental analysis, like EPR, 1H NMR and FT-IR spectroscopy it has been found that clear-cutting, alters C cycling and accelerates decomposition in the forest floor leading to loss of humic fractions in the investigated soils. In the mountain forests the more labile, low-molecular fulvic fraction decreased as the effect of harvesting practice. The transformation of organic matter after clear-cutting resulted in the loss of less humified organic matter containing humic substances of less polymerised molecules. Analysis of the semiquinone radical structures and concentrations showed a decrease in radical concentration observed for HA from mountain clear-cut areas compare to the undisturbed forest. Results presented in this paper have proved less aliphatic character of humic acid molecules from the lowlands, compared to the mountain forest as the effect of clear-cutting. Harvesting practices in mountain regions should be approached with particular care due to the risk of erosion of exposed surfaces and soils containing less humified and less stable organic matter than in the lowlands. Humic fractions of higher solubility, less stability and tendency to migrate through the soil profile may favour the leaching of nutrients and consequently cause the eutrophication of waters.
\end{abstract}

\section{Hosted file}

Jamroz_Jerzykiewicz.pdf available at https://authorea.com/users/400396/articles/512725humic-fractions-as-indicators-of-soil-organic-matter-responses-to-clear-cutting-in-themountain-and-lowland-conditions-of-south-western-poland 


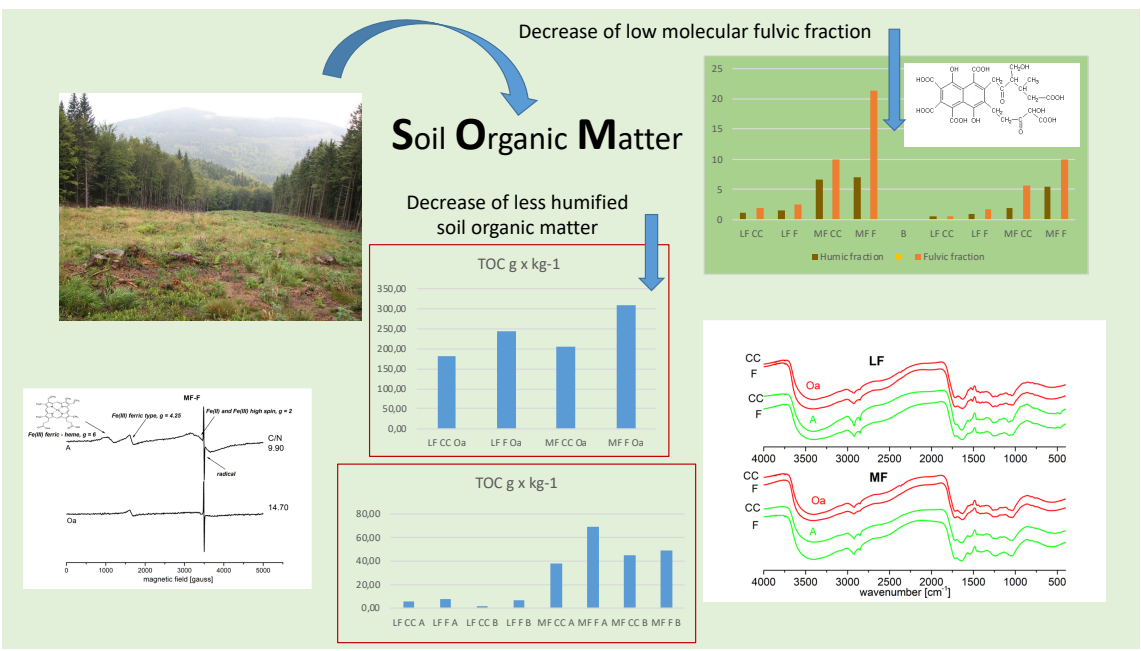

\section{Hosted file}

Tables_and_Figures.pdf available at https://authorea.com/users/400396/articles/512725humic-fractions-as-indicators-of-soil-organic-matter-responses-to-clear-cutting-in-themountain-and-lowland-conditions-of-south-western-poland

\section{Hosted file}

Figures.pdf available at https://authorea.com/users/400396/articles/512725-humic-fractionsas-indicators-of-soil-organic-matter-responses-to-clear-cutting-in-the-mountain-andlowland-conditions-of-south-western-poland 